Wilsey, C. B., C. M. Jensen and N. Miller 2016. Quantifying avian relative abundance and ecosystem service value to identify conservation opportunities in the Midwestern U.S. Avian Conservation and Ecology 11(2):7. http://dx.doi.org/10.5751/ACE-00902-110207

Copyright (C) 2016 by the author(s). Published here under license by the Resilience Alliance.

Research Paper

\title{
Quantifying avian relative abundance and ecosystem service value to identify conservation opportunities in the Midwestern U.S.
}

\author{
Chad B. Wilsey ${ }^{1}$, Caitlin M. Jensen ${ }^{1}$ and Nathaniel Miller ${ }^{2}$
}

${ }^{1}$ National Audubon Society, ${ }^{2}$ Audubon Great Lakes

\begin{abstract}
Grassland birds are highly imperiled because of historical habitat loss and ongoing conversion of grasslands to agricultural and urban land uses. Therefore, prioritizing and further justifying conservation action in remaining grasslands is critical to protecting what remains. Grassland bird conservation has focused on identifying and protecting large grassland complexes referred to as Grassland Bird Conservation Areas (GBCAs). We identified and classified GBCAs in a region highly impacted by both agricultural and urban land conversion using previously developed methods. Then, we extended the analysis to include estimated relative abundance of five grassland focal species in each GBCA. Models of relative abundance were built using eight years of monitoring data collected by citizen scientists. Finally, we quantified the value of ecosystem services provided by each GBCA. There were nearly 55,000 ha of grassland habitats in the Chicago Metropolitan Region that met GBCA criteria, 33\% (18,415 ha) of which were protected. Proportion of abundance in protected versus unprotected areas was similar for Bobolink (Dolichonyx oryzivorus; 46\%), Grasshopper Sparrow (Ammodramus savannarum; 52\%), and Sedge Wren (Cistothorus platensis; 48\%), whereas, Henslow's Sparrow (Ammodramus henslowii; 75\%) had a higher proportion of relative abundance in protected GBCAs and Eastern Meadowlark (Sturnella magna) had lower proportions (37\%). GBCAs provisioned just under $\$ 900$ million annually in ecosystem services, $73 \%$ of which is because of flood control. Outputs of this comprehensive approach will inform grassland bird conservation by providing detailed information about the value for birds and people of grassland habitats.
\end{abstract}

\section{Utilisation de la mesure de l'abondance relative aviaire et de la valeur des écoservices pour déterminer les occasions de conservation dans le Midwest étasunien}

RÉSUMÉ. Les oiseaux de prairie sont grandement menacés en raison des pertes d'habitat subies dans le passé et de la conversion continuelle des prairies à des fins d'agriculture ou d'urbanisation. Ainsi, la priorisation et la justification des mesures de conservation des prairies restantes sont critiques si on veut les protéger. Les mesures actuelles de conservation des oiseaux de prairie reposent surtout sur l'identification et la protection de vastes complexes de prairies, aussi nommés Grassland Bird Conservation Areas (GBCA). Nous avons identifié et classé les GBCA d'une région fortement touchée par la conversion des terres à des fins d'agriculture et d'urbanisation au moyen de méthodes élaborées précédemment. Nous avons ensuite élargi l'analyse pour inclure l'abondance relative de cinq espèces d'oiseaux de prairie estimée dans chaque GBCA. Les modèles d'abondance relative ont été construits à partir de huit années de données récoltées par des citoyens participant à des projets scientifiques. Finalement, nous avons mesuré la valeur des écoservices rendus par chaque GBCA. Près de 55000 ha de milieux de prairie dans la région métropolitaine de Chicago correspondaient aux critères d'un GBCA, dont $33 \%$ (18 415 ha) étaient protégés. L'abondance dans les régions protégées se comparait à celle dans les régions non protégées pour le Goglu des prés (Dolichonyx oryzivorus; $46 \%$ ), le Bruant sauterelle (Ammodramus savannarum; $52 \%$ ) et le Troglodyte à bec court (Cistothorus platensis; $48 \%$ ), tandis qu'elle était plus élevée pour le Bruant de Henslow (Ammodramus henslowii; $75 \%$ ) et plus faible pour la Sturnelle des prés (Sturnella magna; $37 \%$ ) dans les GBCA protégés. Les écoservices fournis par les GBCA se chiffraient tout juste sous la barre des 900 millions de dollars, dont $73 \%$ dans la régulation des inondations. Les résultats de cette approche compréhensive peuvent contribuer à la conservation des oiseaux de prairie en fournissant des renseignements détaillés sur la valeur qu'ont les milieux de prairie sur les oiseaux et les humains.

Key Words: Chicago; ecosystem services; grassland bird conservation areas; relative abundance

\section{INTRODUCTION}

The United States has lost $98 \%$ of its original tallgrass prairie as the result of urban development and vast agricultural expansion (Samson and Knoff 1994), and conversion of grasslands in general continues to outpace restoration (Lark et al. 2015). Grassland bird populations have been among the fastest and most consistently declining suite of species in North America over the past 40 years. Of the 46 North American grassland-breeding birds, $55 \%$ have shown significant declines and $48 \%$ are of conservation concern including four that are federally endangered in the United States (NABCI 2009). An indicator for grassland birds based on 24 grassland-obligate species dropped $40 \%$ from the baseline value set in 1968 (NABCI 2009). In recent years this indicator has stabilized, albeit at historically low levels (NABCI 2014), but recent increases in grassland conversion within the contiguous U.S. to row crops (1-5\% annually; Wright and Wimberley 2013), primarily corn (Lark et al. 2015), may lead to further declines. 
Grassland bird conservation has included the protection of large tracts and complexes of grassland habitat referred to as Grassland Bird Conservation Areas (GBCAs; e.g., Johnson et al. 2010). This framework was developed to prioritize conservation given the sensitivity of many grassland birds to habitat fragmentation (Herkert 1994, Herkert et al. 2003, but see Benson et al. 2013), but GBCA designation does not by itself equate with any level of protection. Designations of GBCAs have been based on expert opinion (CEC and TNC 2005) as well as quantitative geospatial criteria (Sample and Mossman 1997, Johnson et al. 2010). GBCAs include a core area and surrounding matrix and are further classified into types (I-IV). The most valuable GBCAs (Type I) have the largest core area and proportion of grassland in the surrounding matrix. Core patches and their surrounding matrix can be thought of as conservation or management units, for example, when a core is a protected area. GBCAs have been identified in the Prairie Pothole Region of the U.S. (Johnson et al. 2010), and in the states of Missouri and Iowa (Jacobs et al. 2005, 2012). Surprisingly, bird observations are not used to identify or rank GBCAs because the identification process occurs at scales larger than available observational data. Thus, using empirical data to test whether GBCAs are effective in conserving grassland birds is necessary to ensure they effectively contribute to prioritization of conservation actions (Howard et al. 2014, Veloz et al. 2015).

In addition to wild life conservation, grasslands provision valuable ecosystem services. Ecosystem services, or the benefits provided to people by natural resources, enhance the quality of life for people worldwide (Birch et al. 2010, Bateman et al. 2013, Arkema et al. 2015, Ferraro et al. 2015). For example, forest restoration has been found to increase carbon storage and tourism in Latin America and Southeast Asia (Birch et al. 2010, Ferraro et al. 2015); coastal protection has increased fishery and recreational revenues while decreasing damages caused by storms in Latin America and the U.S. (Arkema et al. 2015, Reddy et al. 2016); and targeted land use planning has increased urban green space and bird species diversity in the United Kingdom (Bateman et al. 2013).

Quantifying ecosystem services across a landscape is increasingly used as a method to demonstrate the economic value associated with the protection of natural areas (Polasky et al. 2011, Arkema et al. 2015, Hamel et al. 2015). Additional studies have illustrated the link between ecosystem services and biodiversity conservation (Nelson et al. 2009, Chaplin-Kramer et al. 2015, ReuchlinHugenholtz and McKenzie 2015). It can be valuable for land managers to incorporate the benefits provided by ecosystem services when making decisions regarding land use (Polasky et al. 2011).

We (1) developed regional models of relative abundance for grassland birds based on bird survey data and environmental measures, (2) used those models and landscape configuration attributes to designate GBCAs for regional populations, and (3) estimated the ecosystem services provided by this network of GBCAs. This analysis aimed to inform land management decision making in the Chicago Metropolitan Region by identifying currently unprotected areas that are valuable for both grassland birds and ecosystem services. The work used a multiyear systematic survey of avian abundance collected by citizen scientists to build models of avian relative abundance for five grassland bird species covering a range of habitat requirements: Bobolink (Dolichonyx oryzivorus), Sedge Wren (Cistothorus platensis), Henslow's Sparrow (Ammodramus henslowii), Eastern Meadowlark (Sturnella magna), and Grasshopper Sparrow (Ammodramus savannarum). We estimated relative abundance based on landcover composition and configuration, soils, and vegetation condition. We then classified existing grasslands into four GBCA types and summarized estimates of relative abundance and ecosystem service value from the Chicago Wilderness Green Infrastructure Vision (GIV, described below) for each GBCA.

\section{METHODS}

The project area was defined as the Chicago Metropolitan Region, a $14,615 \mathrm{~km}^{2}$ region including seven metropolitan counties (McHenry, Lake, Kane, DuPage, Cook, Kendall, and Will) surrounding Chicago, Illinois, USA. The regional population is 3.09 million people with roughly 1.04 million living in urban Chicago (U.S. Census Bureau 2010). The study area is a mix of high-density urban, suburban, and rural agricultural land uses.

\section{Observation data}

We built models of relative abundance for five obligate grassland bird species: Bobolink, Eastern Meadowlark, Henslow's Sparrow, Grasshopper Sparrow, and Sedge Wren. Annual five-minute, fixed-radius $(75 \mathrm{~m})$ point counts conducted between 2007 and 2014 were used to estimate avian abundance. All birds seen and heard were counted. Surveys were conducted in the morning (before 09:00) in the month of June. The majority of observations were collected by Bird Conservation Network (http://www. bcnbirds.org) volunteers. Point count data collected by the Lake County Forest Preserves, the Illinois Department of Natural Resources (Will County, IL), and the Illinois Natural History Survey's Critical Trends Assessment Program were also included, but constituted a small proportion $(<1 \%)$ of available data. These were 10-minute counts collected in time increments, and only the first five minutes were used. All surveys were repeated annually at the same point locations. Points were separated by $150 \mathrm{~m}$ and revisited in subsequent years. To reduce sampling bias in the dataset that could lead to a biased abundance model (Boria et al. 2014), we selected only one observation from each sampling location by choosing the year with the maximum abundance (selecting randomly between ties) to minimize the impact of imperfect detection by the volunteer surveyors. Maximum abundance has been shown to more closely reflect true abundance (Toms et al. 2006). We then sampled annual environmental data for the year in which each filtered observation was made.

\section{Environmental data}

Environmental datasets used to predict the relative abundance of the five focal species included landcover, soils, and vegetative condition. We extracted annual landcover from 2007-2014 for the study area from the National Agricultural Statistics Service (USDA) CropScape web service (http://www.cropscape.com; Han et al. 2012).

The 30-meter resolution dataset classifies cropland on an annual basis and utilizes National Landcover Database (Homer et al. 2015) classes for nonagricultural areas. We consolidated cropland and landcover classes into 12 classes (Table 1). Landcover data were summarized in multiple size and configuration metrics at 
each survey point, including the landcover class and patch size, proportion of each consolidated landcover class within one kilometer, and distance to other landcover classes. Also characterized at each point were annual vegetation condition, i.e., greenness measured as normalized difference vegetation index (NDVI), in mid-June, extracted from the VegScape web service (Han et al. 2012), and soil hydrologic group, based on the gridded SSURGO soils dataset (NRCS-USDA [date unknown]). The resulting environmental dataset included 33 predictor variables. Survey time and date were also included as predictors, resulting in a total of 35 variables. All environmental data was summarized at each point location using the raster package (Hijmans 2015) in program R (R Core Team 2014).

Table 1. Environmental data used to predict relative avian abundance including consolidated landcover classes and derived variables, vegetative condition, and soil data.

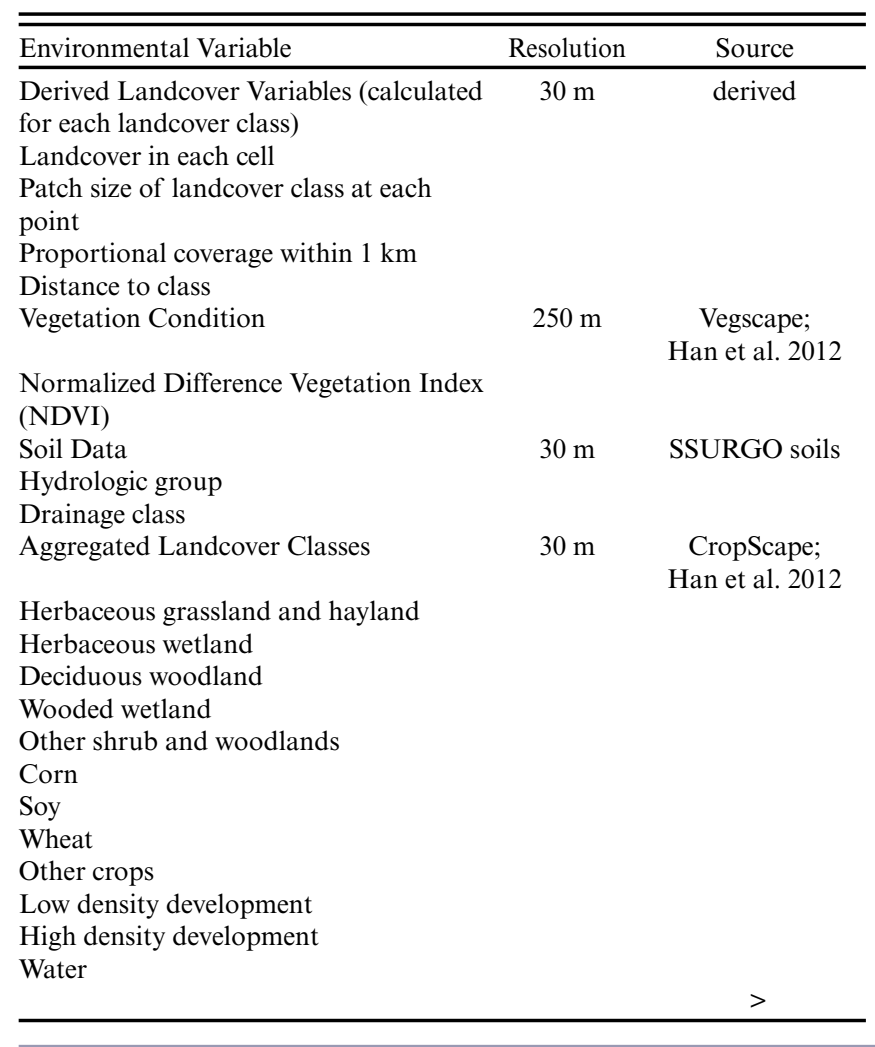

\section{Abundance modeling}

Estimating absolute densities or population sizes from point counts is a challenge (Efford and Dawson 2009). The best available methods require distance estimates or time-of-detection data for each observation, or multiple-observers per count (Farnsworth et al. 2005, Johnson 2008). This information is then used to estimate species-specific detection probabilities that are used to adjust estimated abundances for imperfect detection. Low detection is less of an issue for highly vocal species, such as Western Meadowlark, but can lead to underestimation of density in species that sing from the ground, such as the Grasshopper Sparrow (Leston et al. 2015). The point-count data available for this analysis lacked distance or time-of-detection information. Therefore, we opted to model relative abundance across sites instead of true population size.

We generated models of relative abundance for each species using Boosted Regression Trees (BRTs). BRTs are a machine learning algorithm with high predictive performance able to capture nonlinear relationships between environmental and response variables and interactions among predictor variables (Elith et al. 2008). We built models based on techniques outlined in Elith et al. (2008) using the gbm.step function in the package dismo (Hijmans et al. 2015). We used a Poisson model for count data and set tree complexity to five. Learning rate was adjusted (range: 0.005-0.01) such that at least 1000 trees were used to create each final model (Elith et al. 2008). We used a stepwise variable removal procedure (Elith et al. 2008) to reduce the 33 environmental variables to a smaller set for each species. The stepwise procedure was run on the full dataset using ten-fold cross-validation to assess model performance. We eliminated all predictor variables that showed no sign of improving predictive performance by plotting performance against the number of variables included in the model and identifying the most parsimonious variable set that also maximized performance. The reduced variable set was used in subsequent analyses.

We modeled avian mean relative abundance as the performanceweighted average of 20 BRT models generated for each species (as in Barker et al. 2014). We assessed the performance of each model by cross-validation using spatially stratified subsampling. Spatially stratified subsampling generates robust performance measures because model training and test data are spatially independent (Bahn and McGill 2013). We used semivariograms to explore spatial autocorrelation in our environmental dataset and determined that on average spatial autocorrelation leveled off at distances greater than five kilometers. We then created a novel procedure for building model training and test datasets in which a 5-km resolution grid was overlaid on the study area and all sampling points within randomly selected $5-\mathrm{km}$ grid cells were assigned to either the training or test dataset at a ratio of 5:1 training to test points. Assignments were regulated such that prevalence in training and test dataset had to match prevalence in the full dataset (see Appendix Fig. A1.1 for examples). The output included 20 unique pairs of training and testing data for use in model construction. We assessed model performance based on the Pearson's correlation between observed and predicted abundance.

\section{Relative abundance prediction}

We predicted avian relative abundance as a continuous surface throughout the study area using environmental data from 2014. Relative abundance was estimated as a performance-weighted average of the 20 prediction grids using the Pearson's correlation as the performance measure. We scaled relative abundance to the area of each $30-\mathrm{m}$ grid cell by dividing by the area of each $75-\mathrm{m}$ point count radius and multiplying by the area of each grid cell.

\section{Landscape analysis}

We identified patches of suitable grassland habitat appropriate for landscape-scale conservation from modeled abundances (described above) and landcover. We generated patches of suitable habitat from areas classified as herbaceous grasslands, wheat, other forest and shrub, herbaceous wetlands, and woody wetlands in the Cropland Data Layer (Han et al. 2014) by clumping 
adjacent grid cells into patches. Most grassland birds avoid woody habitat. However, the other forest and shrub and woody wetlands classes were included because comparisons with locally delineated vegetation maps suggested their classification accuracies were low and because they represented a relatively low proportion $(<5 \%)$ of the landscape. Furthermore, these areas are often converted to grasslands through land management and therefore represent a conservation opportunity.

We used criteria for minimum patch size and modeled bird abundance to further refine the patch list. Many grassland birds show evidence of being area sensitive (Herkert 1994, Johnson and Igl 2001, Herkert et al. 2003, Ribic et al. 2009). Yet, recent studies synthesizing information across larger geographic scales suggest that area sensitivity may differ across regions (Ribic et al. 2009). Benson et al. (2013) found little relationship between patch size and nest success in the Midwestern U.S. Walk et al. (2010) demonstrated the importance of small grassland patches for some nesting grassland birds, such as the Eastern Meadowlark. Given the highly fragmented nature of grassland habitats in the study area, we chose to include minimum patch size of 12 ha to avoid overlooking smaller sites that may still be of use to grassland birds. We then removed those patches with modeled relative abundances failing to meet a minimum threshold specific to each species, based on estimated densities from distance sampling conducted previously at a subset of sites. We determined these thresholds by taking the estimated average density found by Buxton (2014) and converting it to the number of birds estimated to be within an area of 12 ha to be consistent with our minimum patch size criterion. We then applied this minimum threshold to all patches, regardless of size. For example, Buxton (2014) found an average density of about 0.95 Bobolink per ha, which translates to a threshold of 11.4 Bobolink across a 12-ha area. We then only included patches with at least 11.4 Bobolink, or another species' minimum threshold. Our rationale assumed that small patches of below-average density were of lower conservation priority and that larger patches supporting this minimum population size were of interest. Thus, the criteria for including small patches was high, while the criteria for including large patches was low. We assumed that large patches with small estimated populations still represented a conservation interest because they could be enhanced through management.

\section{Compiling ecosystem services}

Green infrastructure refers to the network of natural areas that not only support native species but also provide ecosystem services such as water filtration, flood control, and carbon storage. We customized the Chicago Metropolitan Agency for Planning's (CMAP) GIV Summary Tool (available at http://datahub.cmap. illinois.gov) to calculate ecosystem service values for each patch that met the habitat, minimum area, and minimum abundance criteria. This tool uses dollar values (based on existing literature regarding ecosystem services) estimated by The Conservation Fund, which used studies based in the Chicago Metropolitan region when possible (Weber 2014). For example, Pimentel et al. (1997) estimated a water quality value of $\$ 118.30$ associated with each hectare of grassland per year (2006; $\$ 138.91 /$ ha/year in 2014). Also, Costanza et al. (1997) estimated a gas and climate regulation value of $\$ 9.50$ associated with each hectare of grassland per year (2006; \$11.16/ha/year in 2014).
This study focused on four ecosystem services: flood control, groundwater recharge, water purification, and carbon storage (Table 2). We summarized these particular services because these are the only ecosystem services having valuation grids for the region prepared by The Conservation Fund and thus can be quantified using the GIV Summary Tool.

The valuation of these ecosystem services considered several factors, some of which included avoided cost (e.g., from property damages or public health problems that would have occurred in the absence of those services), replacement cost (i.e., the cost of man-made systems that would emulate those services), and factor income (e.g., improved water quality increases commercial fisheries, which increase fishermen incomes; Farber et al. 2002).

Table 2. List of ecosystem services included in valuation by Green Infrastructure Vision (GIV) 2.3 (Allen et al. 2014).

\begin{tabular}{ll}
\hline \hline Ecosystem Service & Description \\
\hline Flood Control & $\begin{array}{l}\text { Maintain water flow stability and protect areas } \\
\text { against flooding } \\
\text { Groundwater Recharge }\end{array}$ \\
$\begin{array}{l}\text { Maintain natural rates of groundwater } \\
\text { recharge and aquifer replenishment } \\
\text { Water Purification }\end{array}$ & $\begin{array}{l}\text { Maintain water quality sufficient for human } \\
\text { consumption, recreational use, and aquatic life } \\
\text { Sequester carbon in vegetation and soils, } \\
\text { thereby reducing greenhouse gases in the } \\
\text { atmosphere and regulating climate }\end{array}$ \\
\hline
\end{tabular}

\section{Protected areas analysis}

We determined how much of each patch is currently protected and unprotected by overlaying each set of patches with a layer representing protected lands (sourced from The Field Museum in Chicago) in the region. We calculated the proportion that is protected and unprotected for each patch and multiplied these proportions by the patch area, bird relative count, and ecosystem service values. This enabled us to identify the largest patches of unprotected habitat and their corresponding values for relative bird abundance and ecosystem services.

\section{Grassland Bird Conservation Area analysis}

We classified patches of suitable habitat into GBCAs using criteria modified from Johnson et al. (2010). Classifications were based on patch size and proportion of grassland cover in the matrix surrounding the patch (Table 3 ). We added a fourth GBCA type to account for the smaller patches found in the Chicago metropolitan region's highly fragmented landscape. Each patch was classified as a Type I, II, III, or IV core based on the area and width of the patch. Next, we calculated the proportion of compatible habitat encompassed by each patch and its matrix, the area enclosed by a $1.6-\mathrm{km}$ buffer surrounding the patch. Type level was assigned based on the lowest criteria met for either patch size or proportion of grassland cover. For example, a $300+$ ha patch with only $32 \%$ grassland within its matrix would be classified as a Type II GBCA. Modeled relative abundance and ecosystem services valuations were then aggregated by GBCA types and protection status. 
Table 3. Criteria for classification of Types I-IV Grassland Bird Conservation Areas (GBCAs). Modified from Johnson et al. (2010).

\begin{tabular}{|c|c|}
\hline Core & A grassland patch consisting of no neutral habitat. \\
\hline Type I core & A grassland patch with area 260 ha and width $1.6 \mathrm{~km}$. \\
\hline Type II core & A grassland patch with area 65 ha and width $0.8 \mathrm{~km}$. \\
\hline Type III core & A grassland patch with area 22 ha and width $0.45 \mathrm{~km}$. \\
\hline Type IV core & A grassland patch with area 12 ha and width $0.3 \mathrm{~km}$. \\
\hline Matrix & A $1.6-\mathrm{km}$ buffer surrounding a core. \\
\hline Type I GBCA & $\begin{array}{l}\text { Designation given to a Type I core having at least } \\
40 \% \text { compatible habitat encompassed by the core and } \\
\text { its matrix. }\end{array}$ \\
\hline Type II GBCA & $\begin{array}{l}\text { Designation given to a Type II core having at least } \\
30 \% \text { or a Type I core having } 30-40 \% \text { compatible } \\
\text { habitat encompassed by the core and its matrix. }\end{array}$ \\
\hline Type III GBCA & $\begin{array}{l}\text { Designation given to a Type III core having at least } \\
20 \% \text { or Types I-II cores having } 20-30 \% \text { compatible } \\
\text { habitat encompassed by the core and its matrix. }\end{array}$ \\
\hline Type IV GBCA & $\begin{array}{l}\text { Designation given to a Type IV core having at least } \\
10 \% \text { or Types I-III cores having } 10-20 \% \text { compatible } \\
\text { habitat encompassed by the core and its matrix. }\end{array}$ \\
\hline
\end{tabular}

\section{RESULTS}

Our full dataset included 8723 point counts completed from $2007-$ 2014 and included multiple counts at the same location. Spatial thinning reduced that to a single record for each species at 1434 locations. Training datasets generated via spatial stratification included 1177 points on average, leaving 257 points for model testing.

The variable removal procedure reduced the 35 environmental variables to $9-16$, depending on the species. Twenty variables in total were used in model construction (Appendix Fig. A1.3). Proportions of land cover within one kilometer of points for grass and hay, high density development, and water were included in all species models. Also included in all models were hydrologic class of soils and time of day. Proportion of corn, soy, and wetlands; distance to grass/hay; and patch size were included in models for four species. Permutation-based variable importance scores were used to rank the contribution of each predictor to overall model performance. Variable response plots were also generated to examine species-habitat relationships (Appendix Figs. A1.4a-e).

Model performance varied among species (Appendix Fig. A1.2). Bobolink had the highest performing model with a median correlation between observed and predicted abundance of 0.62 (range 0.32-0.78) followed by Eastern Meadowlark (0.51 [0.380.63]), Henslow's Sparrow (0.45 [0.26-0.73]), Grasshopper Sparrow $(0.40$ [0.23-0.52]), and Sedge Wren $(0.35$ [0.17-0.60]) by decreasing performance. Model performance was a function of the proportion of nonzero counts (i.e., prevalence) for each modeled species $(F=20.11, p<0.0001)$, suggesting that the paucity of observations available for some species limited our ability to model relative abundance. Overall model performance was low to moderate across species; however, variable response curves suggest that underlying processes are being captured. These included an affinity for high proportions of grass/hay and avoidance of croplands at the landscape scale across species, and preferences for hydric soil types and proximity to water for some species (e.g., Sedge Wren).

Nearly 55,000 ha of grassland habitats in the Chicago Metropolitan Region met GBCA criteria (Fig. A1.3); 33\% (18,415 ha) of which are protected (Fig. 1). The majority of habitat was classified as Type III and IV GBCAs. Type I GBCAs, the largest areas surrounded by high proportions of grasslands, represent the smallest proportion of GBCA-assigned habitat in the region $(3.5 \%)$. A Type I GBCA was more likely to be protected than not, whereas Type III and IV GBCAs were more likely to be unprotected and Type II was approximately half protected (Fig. 1). Protected GBCAs host relatively fewer Eastern Meadowlark $(37 \%)$ than unprotected GBCAs, whereas Henslow's Sparrow $(75 \%)$ had higher relative abundance in protected GBCAs. Proportions of abundance in protected versus unprotected areas were similar for Bobolink (46\%), Grasshopper Sparrow (52\%), and Sedge Wren (48\%). Across species, a bird located in a Type I or II GBCA was more likely to be on protected land than one found on a Type III or IV GBCA. Area-adjusted indices of relative abundance (i.e., a density index) showed higher per-ha densities in protected than unprotected lands. Density indices were similar across GBCAs for the most abundant species: Bobolink and Eastern Meadowlark. Density indices for less common species were higher in Type I and II GBCAs.

Grassland GBCAs provisioned just under $\$ 900$ million annually in ecosystem services based on GIV valuations (Table 4). The majority $(73 \%)$ of that value came from flood control followed by groundwater recharge $(18 \%)$, water purification $(9 \%)$, and carbon sequestration $(<1 \%)$. As with avian abundance, ecosystem services provisioned in Type I and II GBCAs are more likely to be from protected lands than those in Types III and IV. Fifty-five percent of the total valuation for flood control was protected, $42 \%$ for groundwater recharge, $47 \%$ for water purification, and $46 \%$ for carbon sequestration.

Table 4. Total ecosystem service value (\$2014/ac/year) associated with both protected and unprotected portions of each Grassland Bird Conservation Area type.

\begin{tabular}{ll}
\hline \hline Predictor & $\#$ \\
\hline Proportion of grass/hay & 5 \\
Proportion of high-density dev. & 5 \\
Proportion of water & 5 \\
Hydrologic class & 5 \\
Time of day & 5 \\
Proportion of corn & 4 \\
Proportion of soy & 4 \\
Proportion of wetland & 4 \\
Distance to grass/hay & 4 \\
Patch size & 4 \\
Proportion of low-density dev. & 3 \\
Date of survey & 3 \\
Landcover in cell & 3 \\
Distance to soy & 3 \\
Normalized difference vegetation index & 2 \\
Distance to high-density dev. & 1 \\
Distance to low-density dev. & 1 \\
Distance to corn & 1 \\
Distance to wetland & 1 \\
Distance to water & 1 \\
\hline
\end{tabular}


Fig. 1. Type I-IV Grassland Bird Conservation Areas (GBCAs) in the Chicago Metropolitan Region. Type I GBCAs cover a total of 1933 ha; Type II GBCAs cover 11,938 ha; Type III GBCAs cover 25,343 ha; and Type IV GBCAs cover 15,778 ha. See Table 3 for definitions of GBCA types. White areas represent incompatible habitat.

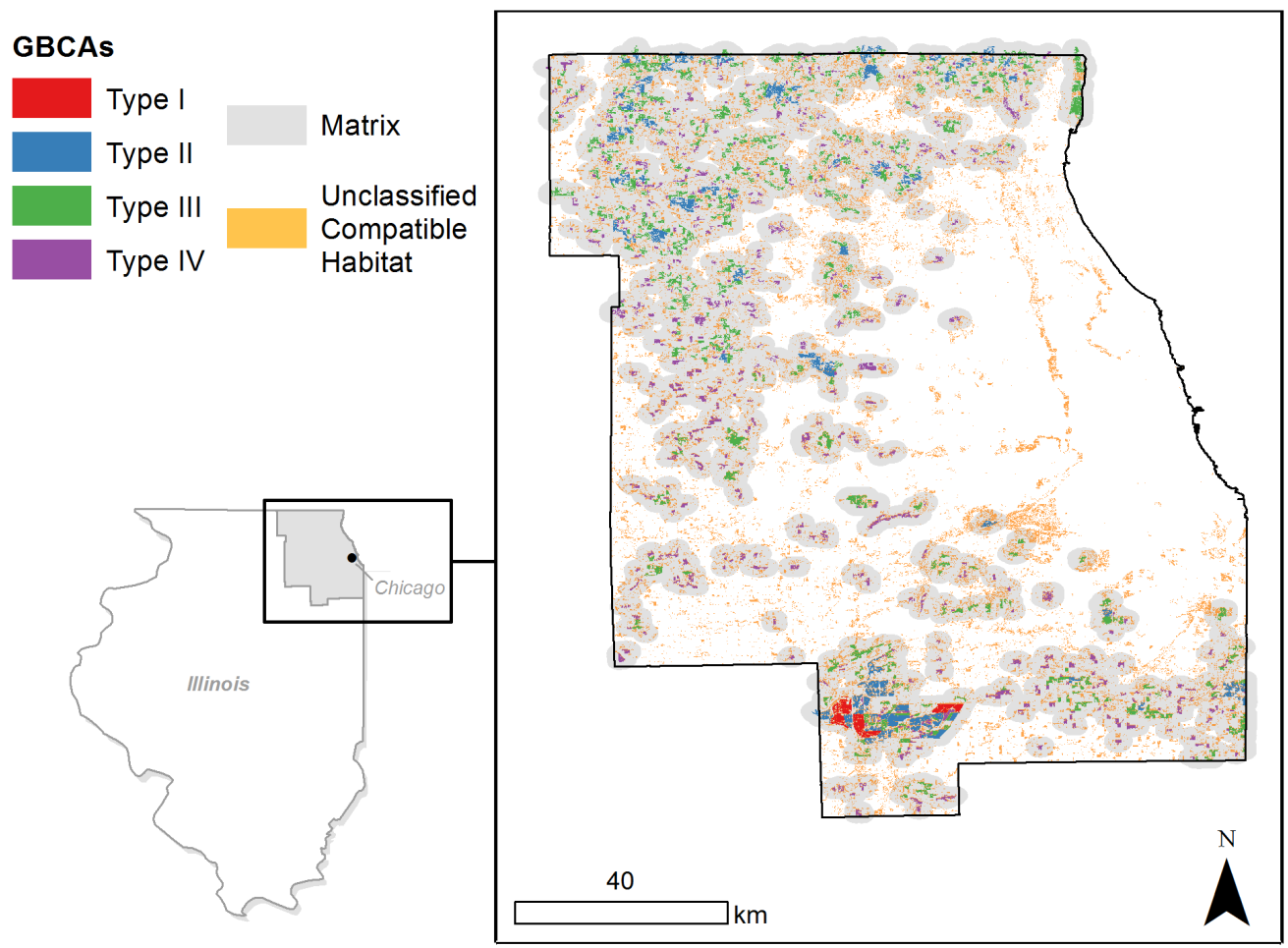

\section{DISCUSSION}

The Chicago Metropolitan Region hosts four Type I GBCAs, 91 Type II GBCAs, and hundreds of Type III and IV GBCAs (Fig. 2 ). Nearly $33 \%$ of these areas are protected. These GBCAs provided important habitat for all five grassland birds modeled. The value of these sites extends beyond their support of wildlife populations to include nearly $\$ 900$ million in ecosystem services. The most valuable of these is flood control, comprising $73 \%$ of the total valuation. Estimates of avian relative abundance and ecosystem services demonstrate the value of these natural habitats and provide justification for protecting currently unprotected areas in the region as well as habitat restoration.

Quantifying value is an initial step in building a robust regional grassland conservation plan. The outputs summarized above characterize the importance of grassland habitats to birds and people in the Chicago Metropolitan Region. On average across species and ecosystem services, less than half of relative abundances and ecosystem services value are currently protected. Remaining unprotected lands are therefore a high-value conservation opportunity. Prioritizing among habitat patches could be done through a spatial optimization routine, treating birds and ecosystem services as conservation objectives (e.g., Ban et al. 2009). Alternatively, priorities could be set through coordination across local land management agencies. Currently, the National Audubon Society is working with county land managers to develop a regional grassland conservation vision based on these data.
Fig. 2. Hectares of protected and unprotected grassland habitat classified as Type I-IV Grassland Bird Conservation Areas (GBCAs). See Table 3 for definitions of GBCA types.

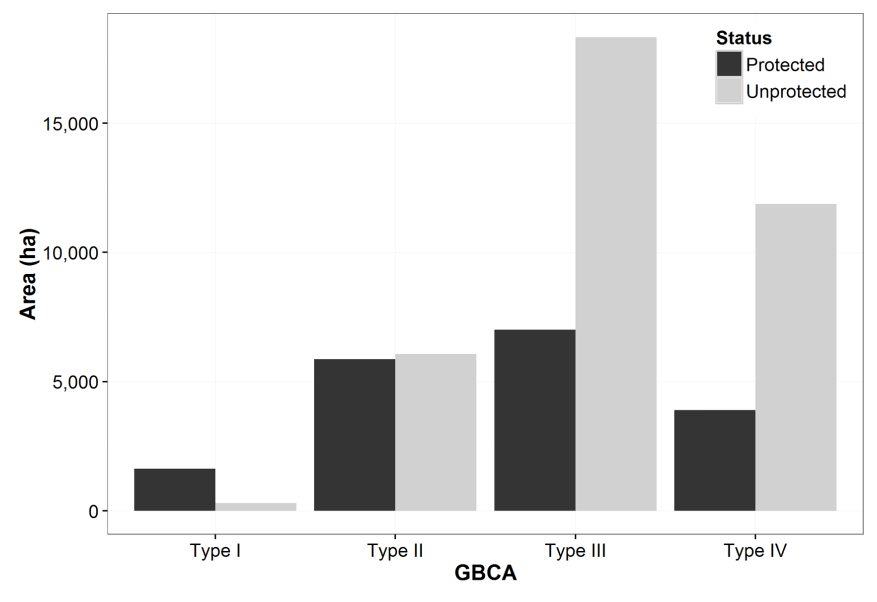

One unexpected result was the high proportion of relative abundance associated with Type III and IV GBCAs. For the most part, this reflects differences in the total area; Type III and IV GBCAs are more than twice the area than Type I and II (Fig. 2). Furthermore, density indices are lower in Type III and IV GBCAs. 
Thus, the return on investment, which is often used to prioritize conservation decisions (Withey et al. 2012), for Type III and IV GBCAs may be lower, at least in terms of relative bird abundance for less common species of high conservation need.

One conceptual model for GBCAs in the northern tallgrass prairie targeted a core patch size of 800 ha surrounded by an additional 1000 ha of grasslands within a 1.6-km buffer (Fitzgerald et al. 1998). Multiple, adjacent Type I GBCAs located within the Midewin National Tallgrass Prairie when combined, would reach this goal. For example, the largest single patch in our analysis (682 ha), also located in Midewin, is surrounded by 2300 ha of grasslands within its $1.6-\mathrm{km}$ matrix buffer. Thus, the Midewin grassland effectively meets the criteria of a premier GBCA. Most (54\%) Type I and II GBCAs are already protected. Therefore, increasing connectivity among these areas, and protecting unprotected Type III and IV GBCAs ( $73 \%$ of which are unprotected) could create additional 1000-ha grasslands with the required matrix of surrounding grasslands. Current land-use change trends are in the opposite direction (Lark et al. 2015), but this could change locally or regionally through federal farm policy. The goal of protected large GBCAs in the Chicago Metropolitan Region is attainable and is desirable for grassland bird conservation and the added benefits of provisioned ecosystem services.

We utilized citizen science data to characterize relative abundance across grassland patches. The use of citizen science data to build models of bird-habitat relationships is relatively new. Comparisons of models built using citizen-collected data versus structured surveys conducted by trained professionals suggest that citizen science is a useful proxy (Munson et al. 2010, Callaghan and Gawlik 2015). We used standard-effort point counts to model relative abundance. In a separate analysis, we converted abundance outputs to densities and compared them to site-level density estimates based on distance sampling for a handful of grasslands in the study area (Buxton 2014). We found our estimates biased high for abundant species (Bobolink and Eastern Meadowlark) and biased low for rare species (Grasshopper Sparrow, Henslow's Sparrow, and Sedge Wren). A bias high for abundant species may suggest a tendency of volunteers to overestimate counts of highly detectable and abundant species. For example, loud vocalizations (e.g., Eastern Meadowlark) may have led observers to include individuals that were $>75 \mathrm{~m}$ away. A bias low for less common species suggests that low detection probabilities are an issue. This is further supported by the presence of detection variables, such as time of day and survey date, in final models (Appendix Figs. A1.4a-e). Therefore, modeling detection probability would likely improve estimates of relative abundance for less common species. In spite of these biases, models of relative abundance did reflect known species-habitat relationships and is therefore a useful measure of relative value across management units (i.e., GBCAs).

Modeled abundance-habitat relationships were consistent with the literature. As expected, proportion of grass and hay was a top variable for all five species. Previous study has found evidence of sensitivity to decreasing grassland patch size for Bobolink, Eastern Meadowlark, Grasshopper Sparrow, and Henslow's Sparrow (Herkert 1994). Patch size was retained in models for these four species. Drivers of abundance among Bobolink, Eastern Meadowlark, Grasshopper Sparrow, and Henslow's
Sparrow were similar. All included some measure of grass/hay, development, and cropland. Meanwhile, Sedge Wren stands out from the group with key predictors relating to water, soils, and variables associated with detection. Previous study suggests that vegetation characteristics drive Sedge Wren occurrence (Herkert 1994). Low performance of the Sedge Wren model, in particular, may reflect the absence of information on local vegetation. Vegetation condition, as measured by NDVI, was not in the top five predictors for any species. NDVI has been used elsewhere to model avian-habitat relationships (Gottschalk et al. 2005), although additional information found in raw reflectance data may improve performance over NDVI (Shirley et al. 2013). Here, landscape composition provided greater information than NDVI for predicting avian abundance. We explored modeling with raw reflectance data in preliminary analyses, but the models underperformed relative to models based on classified landcover and the availability of cloud-free images during the breeding season reduced the available dataset.

The use of classified landcover based on remote sensing in predictive modeling as compared to local vegetation measures introduces additional errors in abundance models. The Cropland Data Layer (Han et al. 2014) has high classification accuracies for agriculture. For example, classification accuracy for corn is $98 \%$. However, natural vegetation classifications are based on the National Landcover Database (Homer et al. 2015), for which accuracy of grasslands and haylands is likely low. Unfortunately, no formal accuracy assessment exists for the National Landcover Database. Refining local landcover data and augmenting it with information on grassland vegetation composition and management, e.g., enrollment in the Conservation Reserve Program, would likely improve model performance.

Ecosystem service valuations from the Chicago Wilderness GIV estimate that grassland habitats provide hundreds of millions of dollars of services annually, largely for flood control. Ecosystem service valuations are helpful for communicating the benefits to society from protecting natural areas (Guerry et al. 2015); however, valuations are still an estimate and have associated errors. In particular, an approach called "benefit transfer" takes a valuation from one location and transfers it to another location with similar landcover (Plummer 2009), but the validity of the transfer is never verified. This characterizes the ecosystem service valuation used here and may lead to overestimation of monetary values if estimates are made in areas of high known value, e.g., along waterways, and transferred to upland areas elsewhere. Furthermore, the dependence of this method on landcover means that ecosystem service valuations are subject to the same underlying errors of the landcover datasets.

Our valuation of ecosystem services associated with grassland bird habitat is limited to four particular ecosystem services, but birds themselves are known to provide ecosystem services (Wenny et al. 2011), such as seed dispersal (Howe and Smallwood 1982, Nathan and Muller-Landau 2000, Cordeiro and Howe 2003), pollination (Feinsinger et al. 1982, Kelly et al. 2004), or pest control for adjacent agriculture (Mols and Visser 2002, Van Bael et al. 2003, Perfecto et al. 2004). Future studies quantifying the monetary value associated with such services will generate further support for GBCAs as highly valuable habitats worthy of protection for the benefit of birds and people. 
Responses to this article can be read online at: http://www.ace-eco.org/issues/responses.php/902

\begin{abstract}
Acknowledgments:
This work was made possible through funding from the U.S. Fish and Wildlife Service Migratory Bird Program and Upper Midwest and Great Lakes Landscape Conservation Cooperative. Special thanks to Katie Koch, John Rogner, Louise Clemency, and Brad Potter for their support and engagement in grassland bird conservation in the Chicago Region. Much of the avian data used in our analysis was collected by the dedicated volunteers of the Bird Conservation Network (BCN). Judy Pollock and Justin Schuetz conceptualized the idea to build abundance models based on citizen science data. Henrik Westerkam supported initial GIS analyses. Dedicated researchers and land managers of the Chicago Wilderness Grassland Bird Committee have contributed data and significant insights and review into this project. The committee includes: James Herkert, Jim Anderson, Gary Glowacki, Chip O'Leary, T.J. Benson, Mike Ward, Cindi Jablonski, Ed Collins, Chris Mulvaney, Brian Kraskiewicz, Scott Meister, Justin Pepper, Robbie Sliwinski, Brook Herman, Drew Ullberg, Jody Strohm, Douglas Stotz, Christine Ribic, John Shuey, and John Legge. Nicole Michel and Lotem Taylor were valuable editors. Ryan Norris and three anonymous reviewers provided comments that improved the manuscript considerably.
\end{abstract}

\section{LITERATURE CITED}

Allen, W., T. Weber, J. Varela, and CMAP Technical Committee. 2014. Green infrastructure vision version 2.3 ecosystem service valuation: final report. The Conservation Fund, Arlington, Virginia, USA.

Arkema, K. K., G. M. Verutes, S. A. Wood, C. Clarke-Samuels, S. Rosado, M. Canto, A. Rosenthal, M. Ruckelshaus, G. Guannel, J. Toft, J. Faries, J. M. Silver, R. Griffin, and A. D. Guerry. 2015. Embedding ecosystem services in coastal planning leads to better outcomes for people and nature. Proceedings of the National Academy of Sciences 112:7390-7395. http://dx.doi.org/10.1073/ pnas. 1406483112

Bahn, V., and B. J. McGill. 2013. Testing the predictive performance of distribution models. Oikos 122:321-331. http:// dx.doi.org/10.1111/j.1600-0706.2012.00299.x

Ban, N. C., C. R. Picard, and A. C. J. Vincent. 2009. Comparing and integrating community-based and science-based approaches to prioritizing marine areas for protection. Conservation Biology 23:899-910. http://dx.doi.org/10.1111/j.1523-1739.2009.01185.x

Barker, N. K. S., S. G. Cumming, and M. Darveau. 2014. Models to predict the distribution and abundance of breeding ducks in Canada. Avian Conservation and Ecology 9(2):7. http://dx.doi. org/10.5751/ACE-00699-090207

Bateman, I. J., A. R. Harwood, G. M. Mace, R. T. Watson, D. J. Abson, B. Andrews, A. Binner, A. Crowe, B. H. Day, S. Dugdale, C. Fezzi, J. Foden, D. Hadley, R. Haines-Young, M. Hulme, A. Kontoleon, A. A. Lovett, P. Munday, U. Pascual, J. Paterson, G. Perino, A. Sen, G. Siriwardena, D. van Soest, and M. Termansen.
2013. Bringing ecosystem services into economic decisionmaking: land use in the United Kingdom. Science 341:45-50. http://dx.doi.org/10.1126/science.1234379

Benson, T. J., S. J. Chiavacci, and M. P. Ward. 2013. Patch size and edge proximity are useful predictors of brood parasitism but not nest survival of grassland birds. Ecological Applications 23:879-887. http://dx.doi.org/10.1890/12-1101.1

Birch, J. C., A. C. Newton, C. A. Aquino, E. Cantarello, C. Echeverría, T. Kitzberger, I. Schiappacasse, and N. T. Garavito. 2010. Cost-effectiveness of dryland forest restoration evaluated by spatial analysis of ecosystem services. Proceedings of the National Academy of Sciences 107:21925-21930. http://dx.doi. org/10.1073/pnas.1003369107

Boria, R. A., L. E. Olson, S. M. Goodman, and R. P. Anderson. 2014. Spatial filtering to reduce sampling bias can improve the performance of ecological niche models. Ecological Modelling 275:73-77. http://dx.doi.org/10.1016/j.ecolmodel.2013.12.012

Buxton, V. 2014. Making the most of what remains: Examining the quality of urban grasslands for birds in Illinois. University of Illinois at Urbana-Champaign. Champaign, Illinois, USA.

Callaghan, C. T., and D. E. Gawlik. 2015. Efficacy of eBird data as an aid in conservation planning and monitoring. Journal of Field Ornithology 86:298-304. http://dx.doi.org/10.1111/jofo.12121

Chaplin-Kramer, R., R. P. Sharp, L. Mandle, S. Sim, J. Johnson, I. Butnar, L. M. i Canals, B. A. Eichelberger, I. Ramler, C. Mueller, N. McLachlan, A. Yousefi, H. King, and P. M. Kareiva. 2015. Spatial patterns of agricultural expansion determine impacts on biodiversity and carbon storage. Proceedings of the National Academy of Sciences 112:7402-7407. http://dx.doi.org/10.1073/ pnas. 1406485112

Commission for Environmental Cooperation and The Nature Conservancy (CEC and TNC). 2005. North American grassland priority conservation areas: technical report and documentation. $\mathbf{J}$. W. Karl and J. Hoth, editors. Commission for Environmental Cooperation and The Nature Conservancy, Montréal, Québec, Canada.

Cordeiro, N. J., and H. F. Howe. 2003. Forest fragmentation severs mutualism between seed dispersers and an endemic African tree. Proceedings of the National Academy of Sciences 100:14052-14056. http://dx.doi.org/10.1073/pnas.2331023100

Costanza, R., R. d'Arge, R. De Groot, S. Faber, M. Grasso, B. Hannon, K. Limburg, S. Naeem, R. V. O’Neill, J. Paruelo, R. G. Raskin, P. Sutton, and M. van den Beltl. 1997. The value of the world's ecosystem services and natural capital. Nature 387:252-259. http://dx.doi.org/10.1038/387253a0

Efford, M. G., and D. K. Dawson. 2009. Effect of distance-related heterogeneity on population size estimates from point counts. Auk 126:100-111. http://dx.doi.org/10.1525/auk.2009.07197

Elith, J., J. R. Leathwick, and T. Hastie. 2008. A working guide to boosted regression trees. Journal of Animal Ecology 77:802-813. http://dx.doi.org/10.1111/j.1365-2656.2008.01390.x

Farber, S. C., R. Costanza, and M. A. Wilson. 2002. Economic and ecological concepts for valuing ecosystem services. Ecological Economics 41:375-392. http://dx.doi.org/10.1016/S0921-8009(02) 00088-5 
Farnsworth, G. L., J. D. Nichols, J. R. Sauer, S. G. Fancy, K. H. Pollock, S. A. Shriner, and T. Simons. 2005. Statistical approaches to the analysis of point count data: a little extra information can go a long way. PSW-GTR-191. U.S. Forest Service, Pacific Southwest Research Station, Albany, California, USA.

Feinsinger, P., J. A. Wolfe, and L. A. Swarm. 1982. Island ecology: reduced hummingbird diversity and the pollination biology of plants, Trinidad and Tobago, West Indies. Ecology 63:494-506. http://dx.doi.org/10.2307/1938966

Ferraro, P. J., M. M. Hanauer, D. A. Miteva, J. L. Nelson, S. K. Pattanayak, C. Nolte, and K. R. E. Sims. 2015. Estimating the impacts of conservation on ecosystem services and poverty by integrating modeling and evaluation. Proceedings of the National Academy of Sciences 112:7420-7425. http://dx.doi.org/10.1073/ pnas. 1406487112

Fitzgerald, J. A., D. N. Pashley, S. J. Lewis, and B. Pardo. 1998. Partners in Flight bird conservation plan for the northern tallgrass prairie (physiographic area 40). American Bird Conservancy, The Plains, Virginia, USA.

Gottschalk, T. K., F. Huettmann, and M. Ehlers. 2005. Review article: thirty years of analysing and modelling avian habitat relationships using satellite imagery data: a review. International Journal of Remote Sensing 26:2631-2656. http://dx.doi. org/10.1080/01431160512331338041

Guerry, A. D., S. Polasky, J. Lubchenco, R. Chaplin-Kramer, G. C. Daily, R. Griffin, M. Ruckelshaus, I. J. Bateman, A. Duraiappah, T. Elmqvist, M. W. Feldman, C. Folke, J. Hoekstra, P. M. Kareiva, B. L. Keeler, S. Li, E. McKenzie, Z. Ouyang, B. Reyers, T. H. Ricketts, J. Rockström, H. Tallis, and B. Vira. 2015. Natural capital and ecosystem services informing decisions: from promise to practice. Proceedings of the National Academy of Sciences 112:7348-7355. http://dx.doi.org/10.1073/pnas.1503751112

Hamel, P., R. Chaplin-Kramer, S. Sim, and C. Mueller. 2015. A new approach to modeling the sediment retention service (InVEST 3.0): case study of the Cape Fear catchment, North Carolina, USA. Science of the Total Environment 524-525:166-177. http://dx.doi.org/10.1016/j.scitotenv.2015.04.027

Han, W., Z. Yang, L. Di, and R. Mueller. 2012. CropScape: a web service based application for exploring and disseminating US conterminous geospatial cropland data products for decision support. Computers and Electronics in Agriculture 84:111-123. http://dx.doi.org/10.1016/j.compag.2012.03.005

Han, W., Z. Yang, L. Di, and P. Yue. 2014. A geospatial web service approach for creating on-demand cropland data layer thematic maps. Transactions of the American Society of Agricultural and Biological Engineers 57:239-247.

Herkert, J. R. 1994. The effects of habitat fragmentation on Midwestern Grassland Bird Communities. Ecological Applications 4:461-471. http://dx.doi.org/10.2307/1941950

Herkert, J. R., D. L. Reinking, D. A. Wiedenfeld, M. Winter, J. L. Zimmerman, W. E. Jensen, E. J. Finck, R. R. Koford, D. H. Wolfe, S. K. Sherrod, M. A. Jenkins, J. Faaborg, and S. K. Robinson. 2003. Effects of prairie fragmentation on the nest success of breeding birds in the midcontinental United States.
Conservation Biology 17:587-594. http://dx.doi.org/10.1046/ j.1523-1739.2003.01418.x

Hijmans, R. J. 2015. raster: Geographic data analysis and modeling. $\mathrm{R}$ package version 2.5-2. The R Project for Statistical Computing, Vienna, Austria. [online] URL: http://CRAN.R-project.org/ package $=$ raster

Hijmans, R. J., S. Phillips, J. Leathwick, and J. Elith. 2015. dismo: Species distribution modeling. $\mathrm{R}$ package version 1.1-1. The $\mathrm{R}$ Project for Statistical Computing, Vienna, Austria. [online] URL: http://CRAN.R-project.org/package=dismo

Homer, C., J. Dewitz, L. Yang, S. Jin, P. Danielson, G. Xian, J. Coulston, N. D. Herold, J. D. Wickham, and K. Megown. 2015. Completion of the 2011 National Land Cover Database for the counterminous United States-representing a decade of land cover change information. Photogrammetric Engineering and Remote Sensing 81:345-354.

Howard, C., P. A. Stephens, J. W. Pearce-Higgins, R. D. Gregory, and S. G. Willis. 2014. Improving species distribution models: the value of data on abundance. Methods in Ecology and Evolution 5:506-513. http://dx.doi.org/10.1111/2041-210X.12184

Howe, H. F., and J. Smallwood. 1982. Ecology of seed dispersal. Annual Review of Ecology and Systematics 13:201-228. http://dx. doi.org/10.1146/annurev.es.13.110182.001221

Jacobs, B., R. R. Korford, F. R. Thompson III, H. Woodward, M. Hubbard, J. A. Fitzgerald, and J. R. Herkert. 2005. Grassland bird conservation efforts in Missouri and Iowa: How will we measure success? Pages 78-82 in. C. J. Ralph and T. D. Rich, editors. Bird conservation implementation and integration in the Americas: Proceedings of the third international Partners in Flight conference. General Technical Report PSW-GTR-191. U.S. Forest Service, Pacific Southwest Research Station, Albany, California, USA.

Jacobs, R. B., F. R. Thompson III, R. R. Koford, F. A. La Sorte, H. D. Woodward, and J. A. Fitzgerald. 2012. Habitat and landscape effects on abundance of Missouri's grassland birds. Journal of Wildlife Management 76:372-381. http://dx.doi. org/10.1002/jwmg.264

Johnson, D. H. 2008. In defense of indices: the case of bird surveys. Journal of Wildlife Management 72:857-868. http://dx. doi.org/10.2193/2007-294

Johnson, D. H., and L. D. Igl. 2001. Area requirements of grassland birds: a regional perspective. Auk 118:24-34. http://dx. doi.org/10.1642/0004-8038(2001)118[0024:AROGBA]2.0.CO;2

Johnson, R. R., D. A. Granfors, N. D. Niemuth, M. E. Estey, and R. E. Reynolds. 2010. Delineating grassland bird conservation areas in the U.S. prairie pothole region. Journal of Fish and Wildlife Management 1:38-42. http://dx.doi.org/10.3996/JFWM-022

Kelly, D., J. J. Ladley, and A. W. Robertson. 2004. Is dispersal easier than pollination? Two tests in New Zealand Loranthaceae. New Zealand Journal of Botany 42:89-103. http://dx.doi. org/10.1080/0028825X.2004.9512892

Lark, T. J., J. M. Salmon, and H. K. Gibbs. 2015. Cropland expansion outpaces agricultural and biofuel policies in the United 
States. Environmental Research Letters 10:044003. http://dx.doi. org/10.1088/1748-9326/10/4/044003

Leston, L., N. Koper, and P. Rosa. 2015. Perceptibility of prairie songbirds using double-observer point counts. Great Plains Research 25:53-61. http://dx.doi.org/10.1353/gpr.2015.0021

Mols, C. M. M., and M. E. Visser. 2002. Great Tits can reduce caterpillar damage in apple orchards. Journal of Applied Ecology 39:888-899. http://dx.doi.org/10.1046/j.1365-2664.2002.00761.x

Munson, M. A., R. Caruana, D. Fink, W. M. Hochachka, M. Iliff, K. V. Rosenberg, D. Sheldon, B. L. Sullivan, C. Wood, and S. Kelling. 2010. A method for measuring the relative information content of data from different monitoring protocols. Methods in Ecology and Evolution 1:263-273. http://dx.doi.org/10.1111/ j.2041-210x.2010.00035.x

Nathan, R., and H. C. Muller-Landau. 2000. Spatial patterns of seed dispersal, their determinants and consequences for recruitment. Trends in Ecology \& Evolution 15:278-285. http://dx. doi.org/10.1016/S0169-5347(00)01874-7

Natural Resources Conservation Service, United States Department of Agriculture (NRCS-USDA), Soil Survey Staff. [date unknown]. Gridded soil survey geographic (gSSURGO) database. United States Department of Agriculture, Washington, D.C., USA. [online] URL: http://datagateway.nrcs.usda.gov/

Nelson, E., G. Mendoza, J. Regetz, S. Polasky, H. Tallis, D. R. Cameron, K. M. Chan, G. C. Daily, J. Goldstein, P. M. Kareiva, E. Lonsdorf, R. Naidoo, T. H. Ricketts, and M. R. Shaw. 2009. Modeling multiple ecosystem services, biodiversity conservation, commodity production, and tradeoffs at landscape scales. Frontiers in Ecology and the Environment 7:4-11. http://dx.doi. org/10.1890/080023

North American Bird Conservation Initiative, U.S. Committee (NABCI). 2009. The state of the birds 2009 report. U.S. Department of Interior, Washington, D.C., USA.

North American Bird Conservation Initiative, U.S. Committee (NABCI). 2014. The state of the birds 2014 report. U.S. Department of Interior, Washington, D.C., USA.

Perfecto, I., J. H. Vandermeer, G. L. Bautista, G. I. Nunñez, R. Greenberg, P. Bichier, and S. Langridge. 2004. Greater predation in shaded coffee farms: the role of resident Neotropical birds. Ecology 85:2677-2681. http://dx.doi.org/10.1890/03-3145

Pimentel, D., C. Wilson, C. McCullum, R. Huang, P. Dwen, J. Flack, Q. Tran, T. Saltman, and B. Cliff. 1997. Economic and environmental benefits of biodiversity. BioScience 47:747-757. http://dx.doi.org/10.2307/1313097

Plummer, M. L. 2009. Assessing benefit transfer for the valuation of ecosystem services. Frontiers in Ecology and the Environment 7:38-45. http://dx.doi.org/10.1890/080091

Polasky, S., E. Nelson, D. Pennington, and K. A. Johnson. 2011. The impact of land-use change on ecosystem services, biodiversity and returns to landowners: a case study in the State of Minnesota. Environmental and Resource Economics 48:219-242. http://dx.doi. org/10.1007/s10640-010-9407-0
R Core Team. 2014. R: A language and environment for statistical computing. R Foundation for Statistical Computing, Vienna, Austria. [online] URL: http://www.R-project.org/

Reddy, S. M. W., G. Guannel, R. Griffin, J. Faries, T. Boucher, M. Thompson, J. Brenner, J. Bernhardt, G. Verutes, S. A. Wood, J. A. Silver, J. Toft, A. Rogers, A. Maas, A. Guerry, J. Molnar, and J. L. DiMuro. 2016. Evaluating the role of coastal habitats and sea-level rise in hurricane risk mitigation: an ecological economic assessment method and application to a business decision. Integrated Environmental Assessment and Management 12:328-44. http://dx.doi.org/10.1002/ieam.1678

Reuchlin-Hugenholtz, E., and E. McKenzie. 2015. Marine protected areas: smart investments in ocean health. World Wide Fund, Gland, Switzerland.

Ribic, C. A., R. R. Koford, J. R. Herkert, D. H. Johnson, N. D. Niemuth, D. E. Naugle, K. K. Bakker, D. W. Sample, and R. B. Renfrew. 2009. Area sensitivity in North American grassland birds: patterns and processes. Auk 126:233-244. http://dx.doi. org/10.1525/auk.2009.1409

Rowe, H. I. 2010. Tricks of the trade: techniques and opinions from 38 experts in tallgrass prairie restoration. Restoration Ecology 18:253-262. http://dx.doi.org/10.1111/j.1526-100X.2010.00663. $\mathrm{x}$

Sample, D. W., and M. J. Mossman. 1997. Managing habitat for grassland birds: a guide for Wisconsin. Wisconsin Department of Natural Resources, Madison, Wisconsin, USA.

Samson, F., and F. Knopf. 1994. Prairie conservation in North America. BioScience 44:418-421. http://dx.doi.org/10.2307/1312365

Shirley, S. M., Z. Yang, R. A. Hutchinson, J. D. Alexander, K. McGarigal, and M. G. Betts. 2013. Species distribution modelling for the people: unclassified landsat TM imagery predicts bird occurrence at fine resolutions. Diversity and Distributions 19:855-866. http://dx.doi.org/10.1111/ddi.12093

Toms, J. D., F. K. A. Schmiegelow, S. J. Hannon, and M.-A. Villard. 2006. Are point counts of boreal songbirds reliable proxies for more intensive abundance estimators? Auk 123:438-454. http://dx.doi.org/10.1642/0004-8038(2006)123[438: APCOBS]2.0.CO;2

U.S. Census Bureau. 2010. Census 2010, Summary File 1. U.S. Census Bureau, Washington, D.C., USA.

Van Bael, S. A., J. D. Brawn, and S. K. Robinson. 2003. Birds defend trees from herbivores in a Neotropical forest canopy. Proceedings of the National Academy of Sciences 100:8304-8307. http://dx.doi.org/10.1073/pnas. 1431621100

Veloz, S., L. Salas, B. Altman, J. Alexander, D. Jongsomjit, N. Elliott, and G. Ballard. 2015. Improving effectiveness of systematic conservation planning with density data: improving systematic conservation planning. Conservation Biology 29:1217-1227. http://dx.doi.org/10.1111/cobi.12499

Walk, J. W., E. L. Kershner, T. J. Benson, and R. E. Warner. 2010. Nesting success of grassland birds in small patches in an agricultural landscape. Auk 127:328-334. http://dx.doi.org/10.1525/ auk.2009.09180 
Weber, T. 2014. Green infrastructure vision version 2.3 ecosystem service valuation: ecosystem services literature review. The Conservation Fund, Arlington, Virginia, USA.

Wenny, D. G., T. L. Devault, M. D. Johnson, D. Kelly, C. H. Sekercioglu, D. F. Tomback, and C. J. Whelan. 2011. The need to quantify ecosystem services provided by birds. Auk 128:1-14. http://dx.doi.org/10.1525/auk.2011.10248

Withey, J. C., J. J. Lawler, S. Polasky, A. J. Plantinga, E. J. Nelson, P. Kareiva, C. B. Wilsey, C. A. Schloss, T. M. Nogeire, A. Ruesch, J. Ramos Jr, and W. Reid. 2012. Maximising return on conservation investment in the conterminous USA. Ecology Letters 15:1249-1256. http://dx.doi.org/10.1111/j.1461-0248.2012.01847.

$\mathrm{x}$

Wright, C. K., and M. C. Wimberly. 2013. Recent land use change in the Western Corn Belt threatens grasslands and wetlands. Proceedings of the National Academy of Sciences 110:4134-4139. http://dx.doi.org/10.1073/pnas. 1215404110 


\section{Appendix 1. Supplementary information on Boosted Regression Trees.}

\section{Spatially stratified sampling}

We generated 20 training and test datasets for each modeled species in order to accurately assess model performance and to generate ensemble estimates of abundance robust to the data partitioning process (Barker et al. 2014). Training and test datasets were generated using a masked geographically structured (Radosavljevic and Anderson 2014) sub-setting routine that randomly assigns points to training and test datasets at a ratio of 5:1 based on a 5-km grid overlaid on the study area. This results in 20 unique sets of training and test data (Figure A1.1).

Figure A1.1. Sample training datasets generated by a spatial stratification algorithm used to generate datasets for model training and evaluation. Spatial stratification produces robust assessments of model performance. The algorithm assures that prevalence in the training and test datasets is similar to the full dataset.

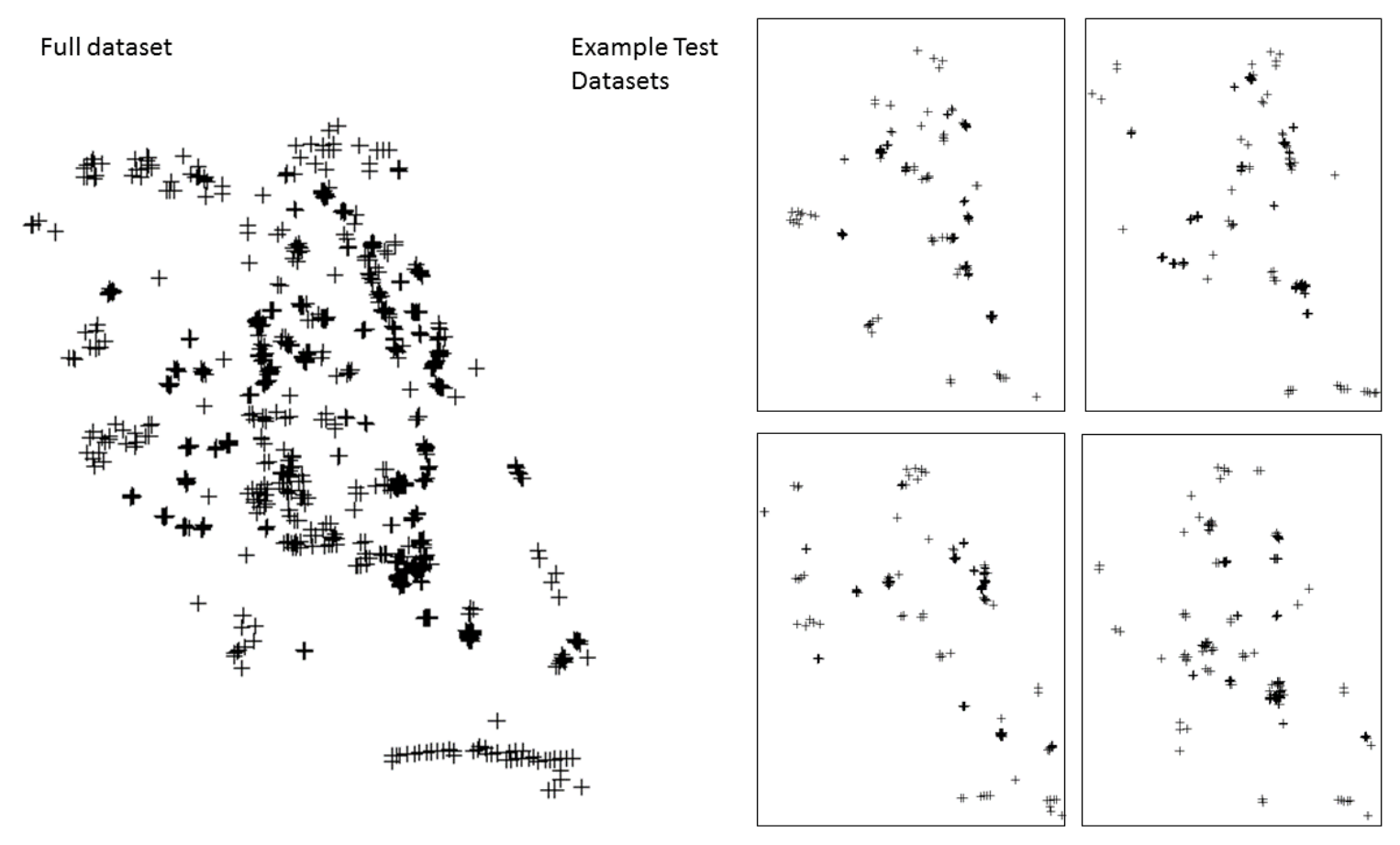

\section{Model performance}

We characterized model performance by the median correlation across the 20 independent datasets. Correlation measures showed a significant positive relationship with the availability of non-zero counts, suggesting that more counts of rare birds would improve models of their relative abundance.

Figure A1.2. Model performance as measured by the correlation between predicted and observed abundance increased with increasing prevalence across five species of grassland birds: Sedge Wren (sedwre), Henslow's Sparrow (henspa), Grasshopper Sparrow (graspa), Bobolink (boboli), and Eastern Meadowlark (easmea). Open circles correspond to each of 20 models of relative abundance built for each species. Closed circles mark the median performance across those models. There is a significant 
positive relationship between performance and prevalence across these five species ( $F=20.11$, $\mathrm{p}<0.0001)$.

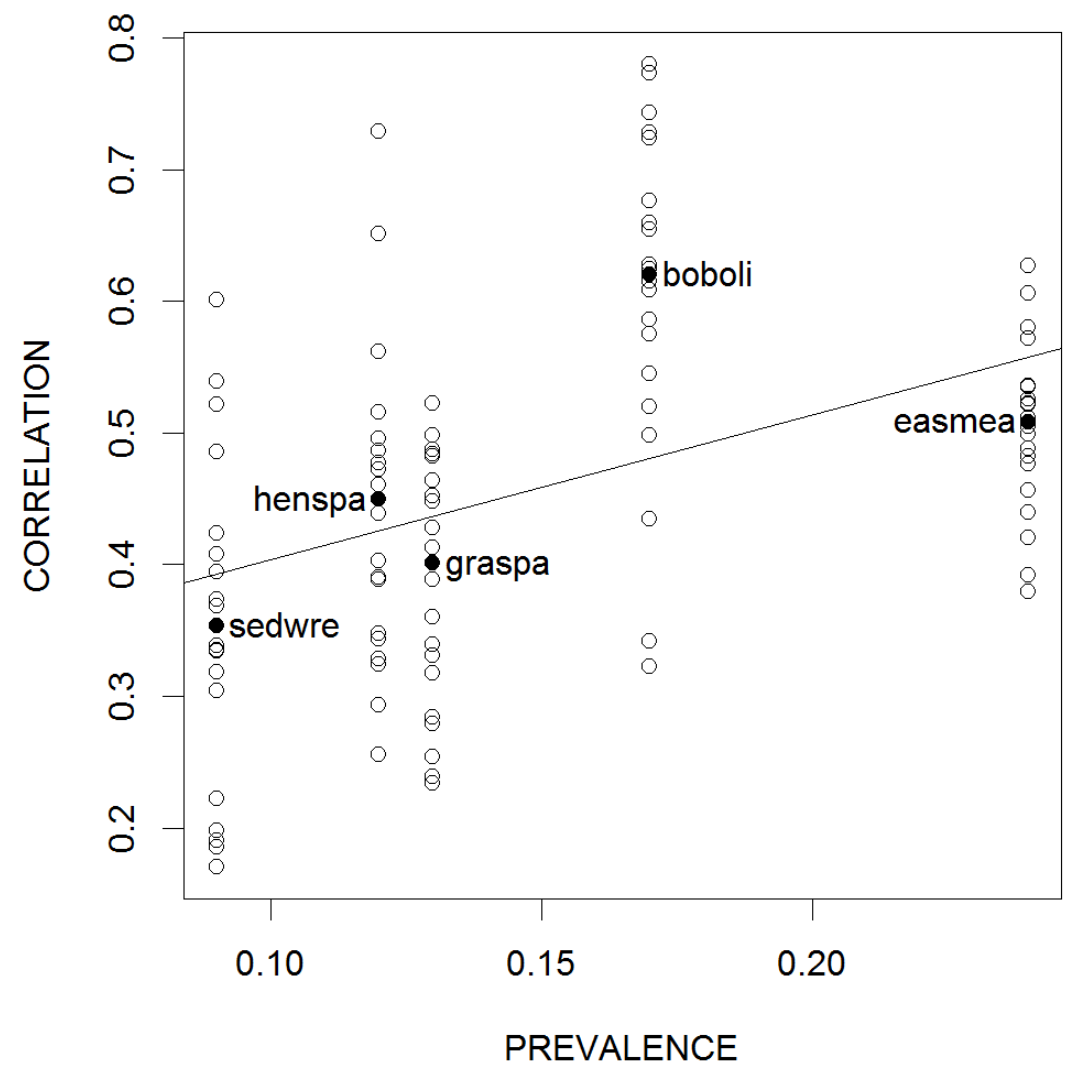

\section{Covariate relationships}

Boosted regression tree models parameterize linear and non-linear responses between environmental covariates and observed relative abundance. Models were build using a backward stepwise procedure in which variables that did not contribute to improving model performance were removed. Figure A1.3 shows the frequency with which each environmental variable was included in models across species. Variable importance values within each model are estimated by random permutation of input variables for a given variable and estimating the impact on model accuracy. The top five environmental covariates for each species have the greatest impact on model accuracy and therefore are most closely related to relative abundance. Table A1.1 lists the top five predictor variables for each modeled species.

Variable response plots for boosted regression trees capture the shape of the average response to a given environmental predictor variable while other predictors are held at an intermediate value.

Response plots (Figures A1.4a-e, see below) for each species are plot on a common scale. Values $>0$ on the $y$ axis suggest a positive response of abundance to a given predictor with negative values suggesting the opposite. Larger response values imply a greater effect size. Variables are listed in order of their permutation-based variable importance. Plots were generated using the gbm.plot function in package dismo of R (Hijmans et al. 2015). 
Figure A1.3. Frequency at which environmental variables were included in models of relative avian abundance for five species of grassland birds.

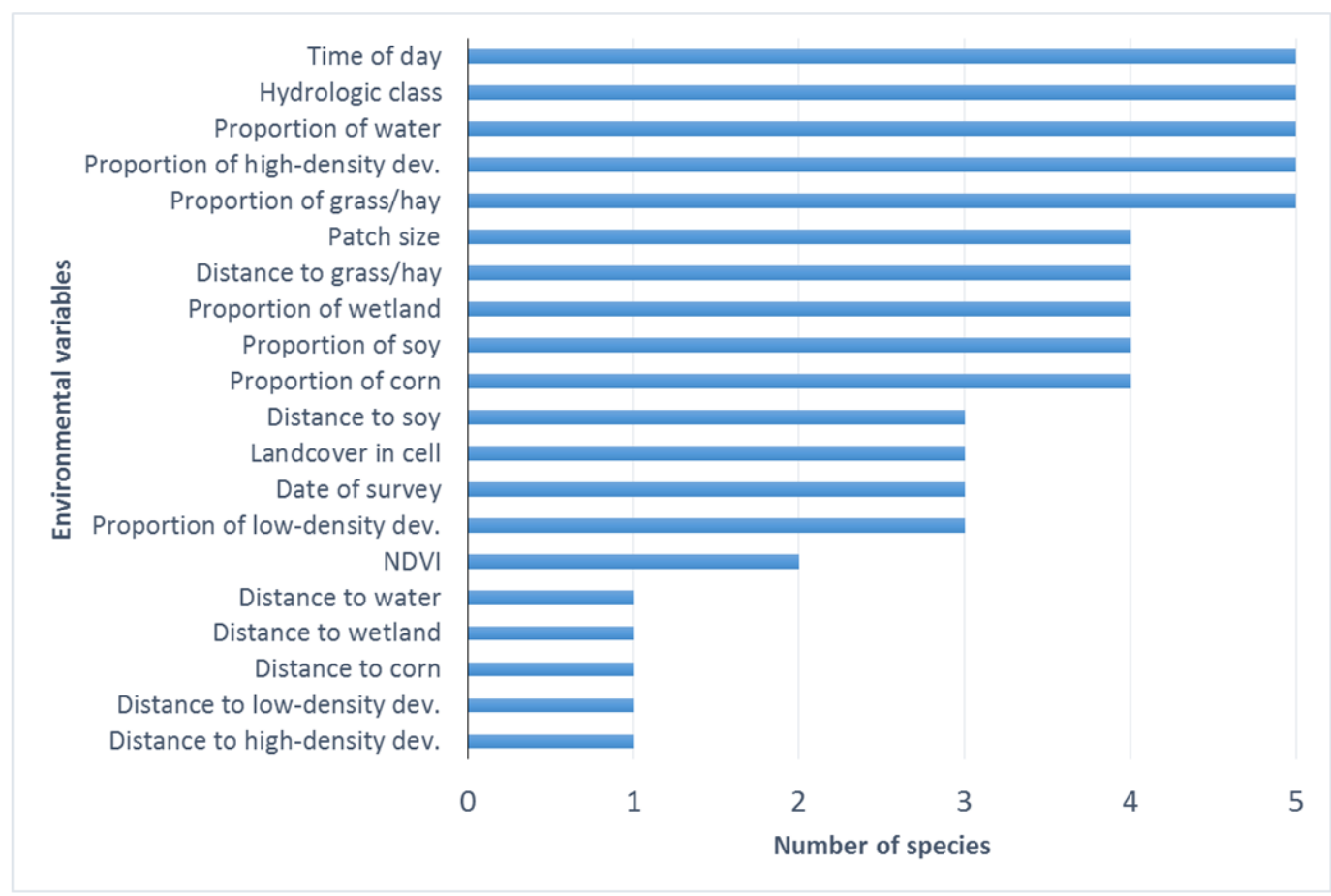

Table A1.1. Top five predictor variables for each species based on permutation-based variable importance.

\begin{tabular}{ll} 
Species & Predictor \\
\hline Bobolink & Proportion of grass/hay \\
& Patch size \\
& Proportion of soy \\
& Proportion of water \\
& Proportion of high density development \\
Sedge Wren & Proportion of grass/hay \\
& Proportion of water \\
& Time of day \\
& Survey date \\
& Hydrological class \\
Henslow's Sparrow & Time of survey \\
& Proportion of grass/hay \\
& Proportion of soy \\
& Distance to grass/hay \\
& Hydrologic class \\
& Proportion of grass/hay \\
Eastern Meadowlark & Proportion of soy \\
& Distance to soy \\
& Proportion of low density development \\
& Landcover in cell \\
& Proportion of grass/hay \\
& Proportion of soy \\
& Distance to soy \\
& Proportion of low density development \\
& Landcover in cell
\end{tabular}




\section{References}

Barker, N. K. S., S. G. Cumming, and M. Darveau. 2014. Models to predict the distribution and abundance of breeding ducks in Canada. Avian Conservation and Ecology 9. doi: 10.5751/ACE-00699090207.

Robert J. Hijmans, Steven Phillips, John Leathwick and Jane Elith (2015). dismo: Species Distribution Modeling. R package version 1.1-1. https://CRAN.R-project.org/package=dismo

Radosavljevic, A., and R. P. Anderson. 2014. Making better Maxent models of species distributions: complexity, overfitting and evaluation. Journal of biogeography 41:629-643. 
Figure A1.4a. Response curves for Bobolink
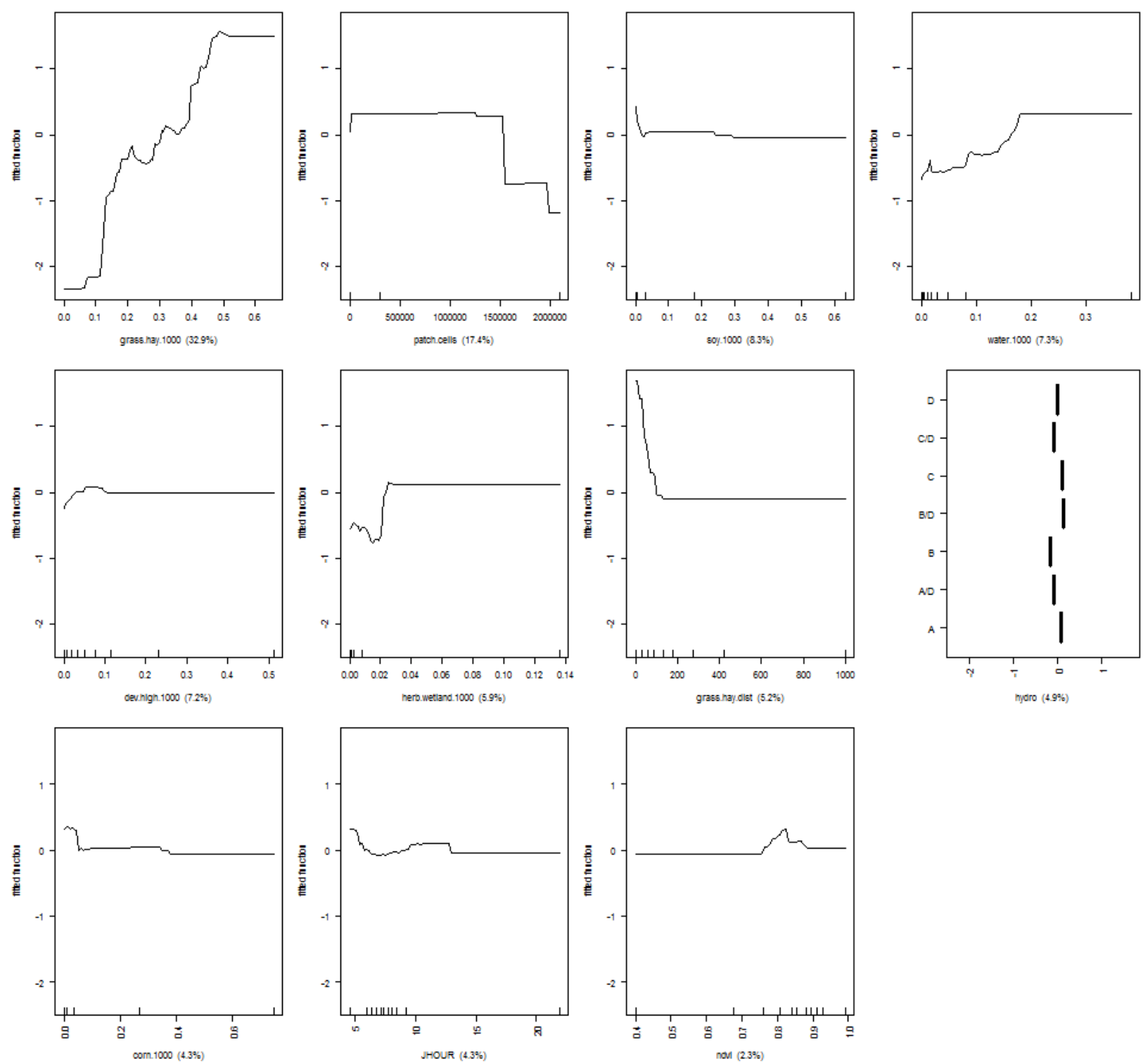
Figure A1.4b. Response curves for Eastern Meadowlark
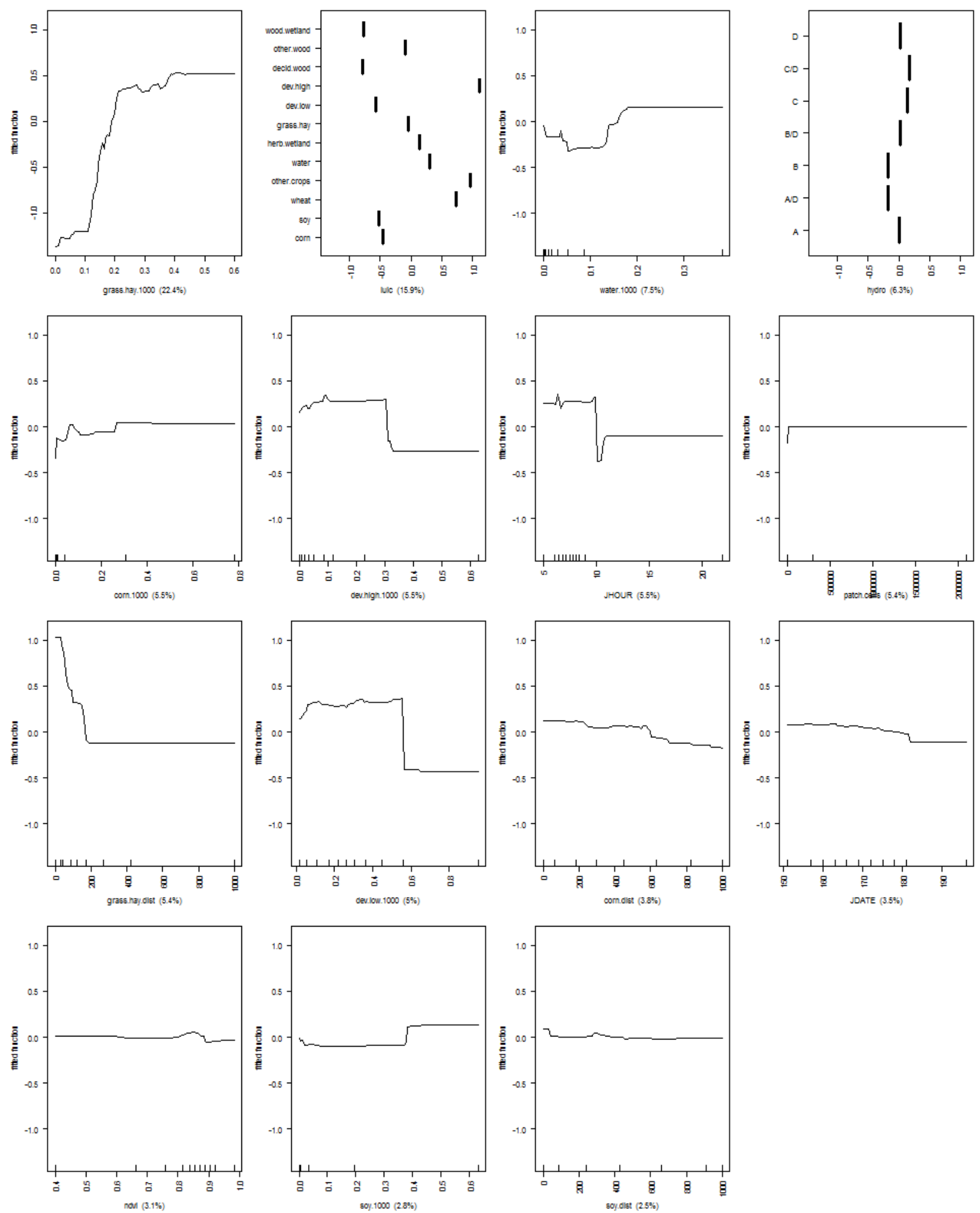
Figure A1.4c. Response curves for Grasshopper Sparrow
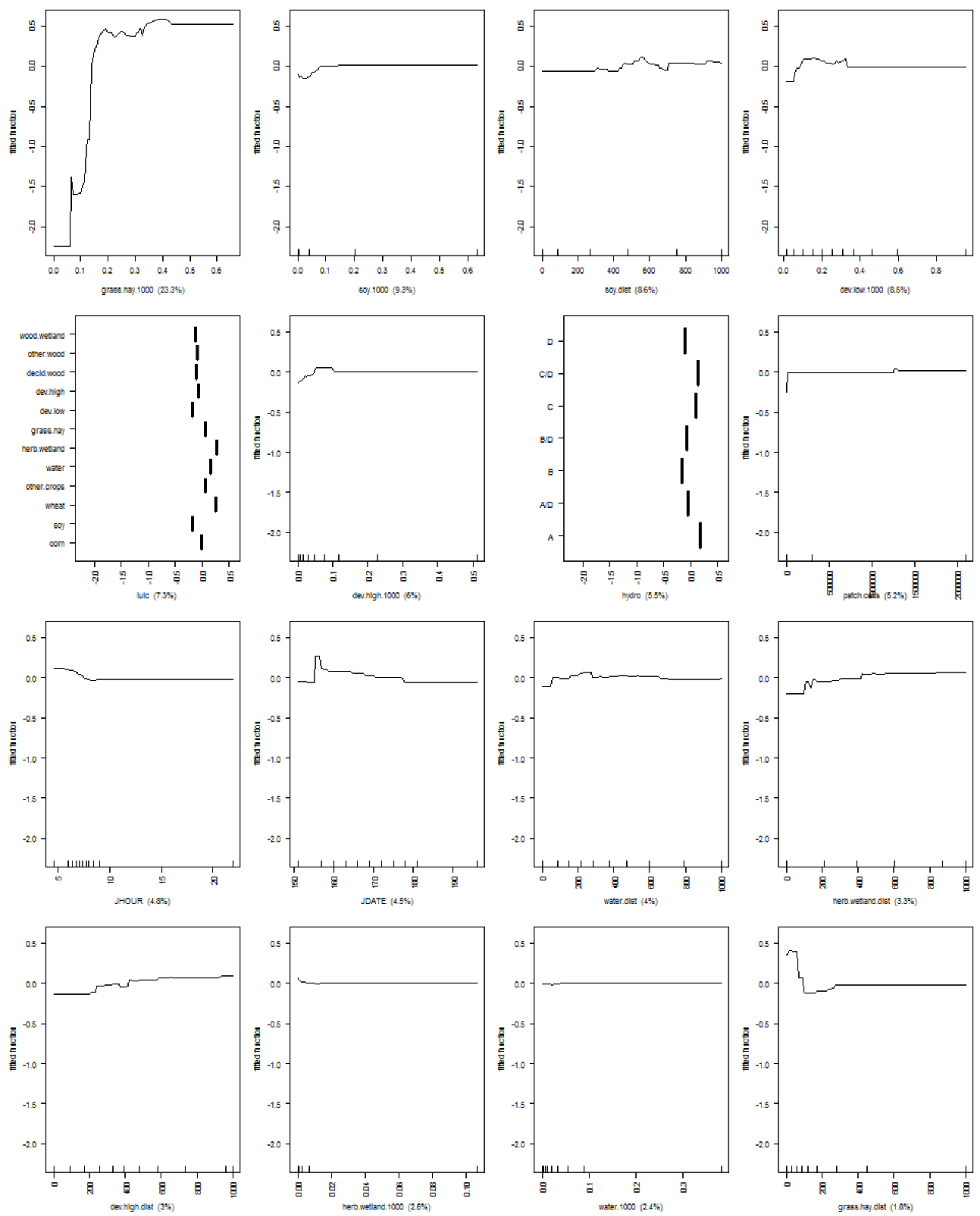
Figure A1.4d. Response curves for Henslow's Sparrow
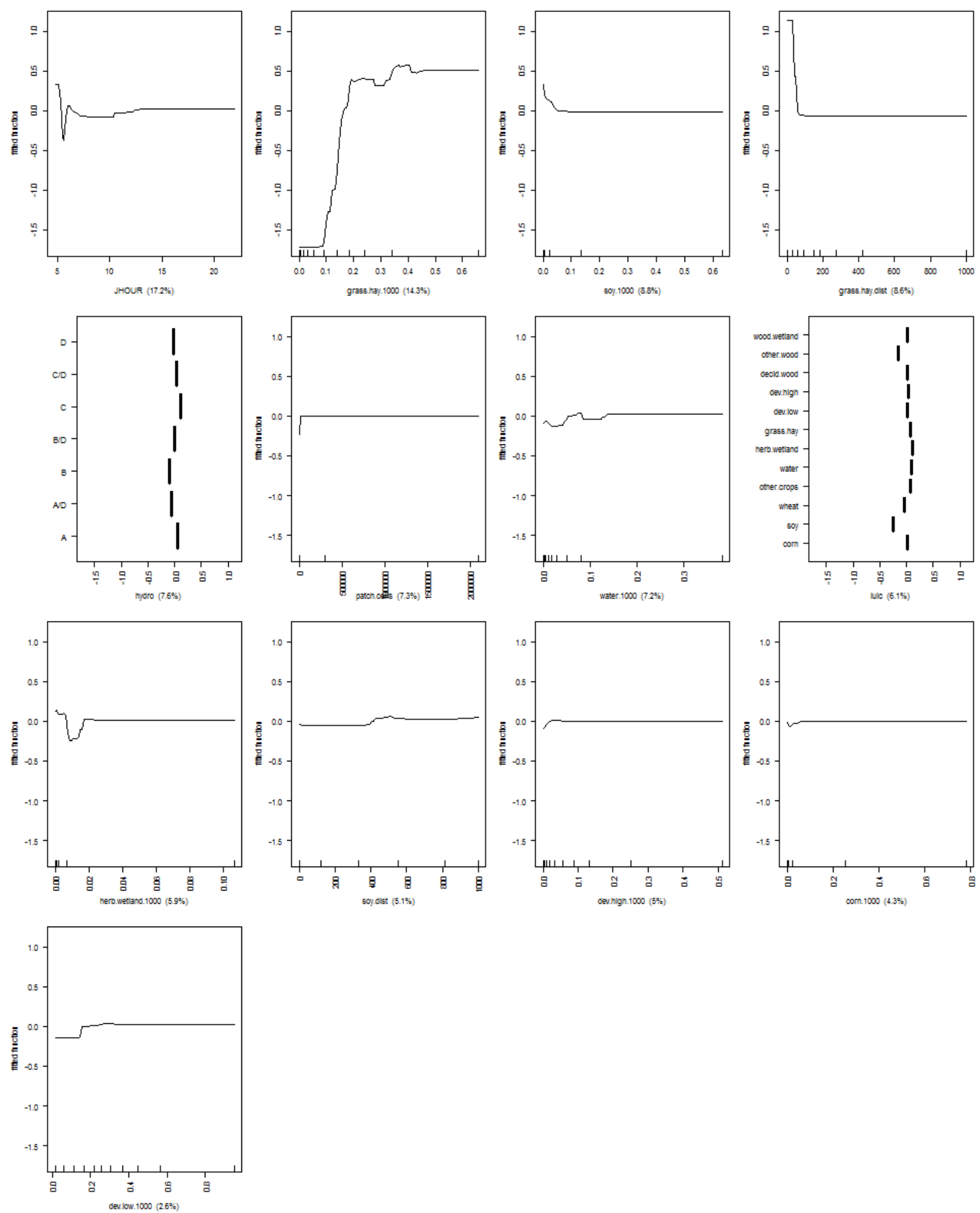
Figure A1.4e. Response curves for Sedge Wren
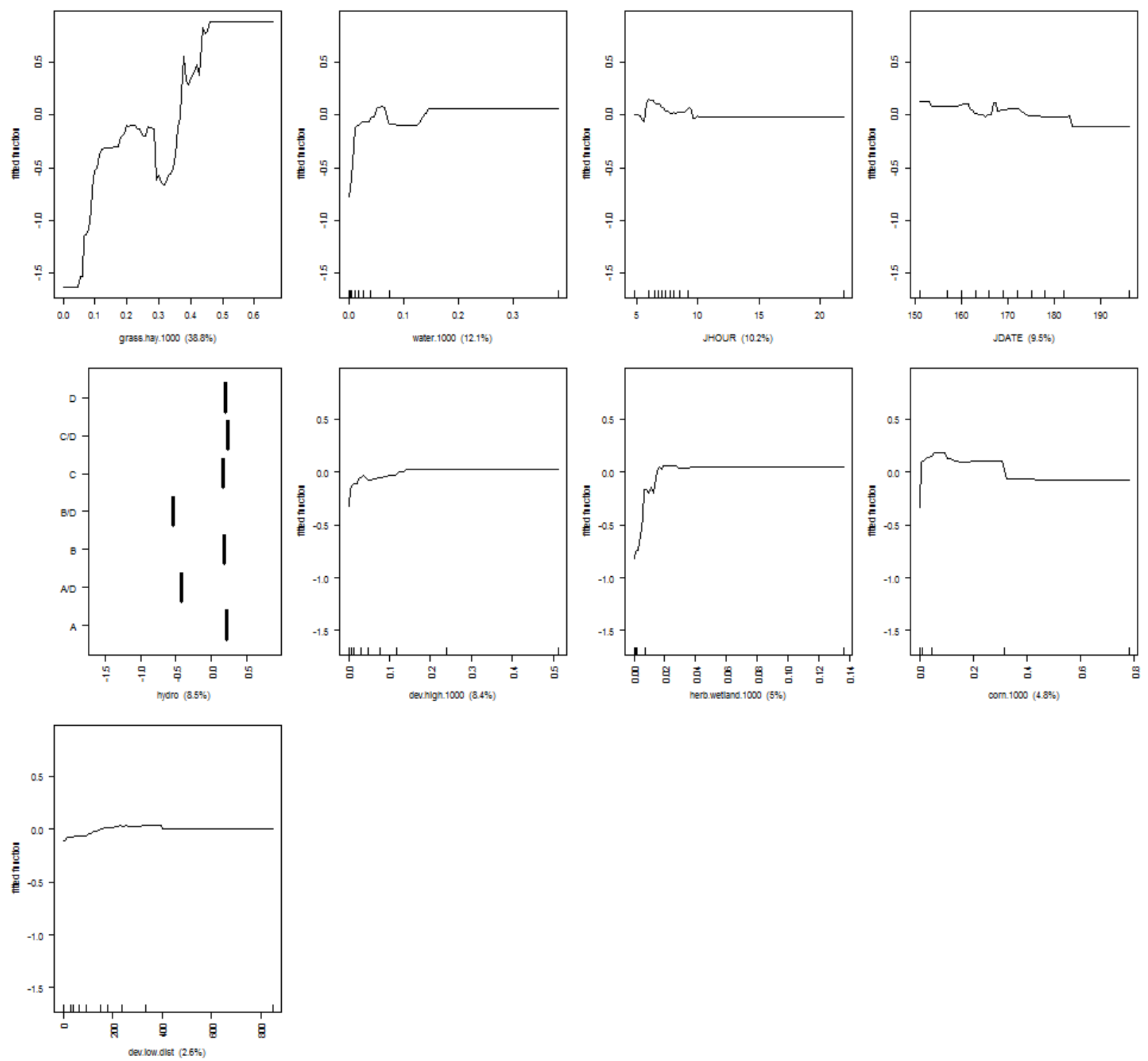